\title{
Articles
}

\section{Administrative Liability for Causing Damage to Selected Components of the Environment}

\author{
Branislav Cepek* \\ * Branislav Cepek, Associate Professor, PhD, Paneuropean University in Bratislava, Faculty of Law, \\ Institute of Public Law. (e-mail: branislav.cepek@paneurouni.com)
}

\begin{abstract}
The article deals with one of the most important and recent issues of the contemporary law of the Member States and the EU in the field of environment, which is criminal liability for environmental crimes which serves as a tool for promoting environmental protection. Environmental law can be divided into two basic types of environmental liability for damage to the environment and liability for damage. Liability for environmental damage is divided into civil liability for damage as well as liability of the public for ecological damage. A special case is liability for historical damage. The Directive on torts is divided into criminal liability and administrative liability. In this paper, the author focuses on the analysis of the contemporary Czech tort law in the field of biodiversity protection and considers several aspects of this a de lege ferenda issue.
\end{abstract}

Keywords: environmental law; administration; law; liability for damage to the environment

\section{Introduction}

In connection with the legal-theoretical research into the subject matter of environmental liability, the legal science, before the adoption of Act No. 17/1992 Coll. on Environment, drew attention to a number of specific features of the regime of administrative and legal liability allowing, within the de lege ferenda considerations, to "incorporate" the provisions related to compensation, or more precisely, to restoration of environmental loss. Professional legal literature deals mostly with the issue of imposing individual types of sanctions.

In the following article, my intention is to give an analysis of the Slovak legal arrangements of liability in tort in the field of biodiversity protection, further, to compare it partly with the Czech legislation and consider some aspects of this issue de lege ferenda. I choose liability in tort in the field of biodiversity protection of the ecosystems because it ranks among one of the most important environmental components, where the most scientific research has been done into, but it is also one of the most sensitive components regarding the change in environment. Biodiversity is, in a broader sense, the diversity of species of 
the living organisms (plants, fungi, animals and one celled organisms of the living world); we do not discuss only those species that are generally known.

In situ protection remains the most effective approach towards biodiversity protection. It means protection of the ecosystems and natural habitats, including maintaining and restoring viable species populations in their natural habitat. An important part of in situ protection is the management of specially protected areas of national and international importance, ensuring the ecological networks of functional habitats, including the restoration of destroyed habitats and the conservation of species within natural habitats. ${ }^{1}$

In the Slovak environmental law, the general regulation of administrative and legal liability for administrative offences in environmental protection is contained in Act No. 17/1992 Coll. on Environment, namely in the section called "Liability for a breach of obligations while protecting the environment". Provision 28 sets forth the general regulation of sanctioning/punitive liability, i.e. liability in tort. A sanction, at the set amount, can be imposed only on a natural person or legal person that is authorised to engage in business who while doing their activity causes some environmental harm by breaching laws, or fails to take measures that would lead to correction, or fails to warn some competent authority that there is a threat of harm to the environment. Pursuant to Section 2 of this provision, a fine may be imposed only within one year since the day on which the environmental authority ascertained the breach of obligations, but no later than three years since the date on which the breach occurred. However, environmental law does not regulate the jurisdiction of the state sanctioning authorities under the cited provision, and thus the practical application of this provision is practically excluded. However, the need for such a provision is rather arguable, especially in the view of the fact that laws in question contain specific provisions which regulate the breach of obligations in each of the environmental sectors. ${ }^{2}$

\section{Protection of Biodiversity under Special Provisions}

For the specific actus reus of administrative offences, it is necessary to investigate in special legal regulations, namely in the area of sources of environmental law (especially Act No. 543/2002 Coll. on Nature and Landscape Protection) and further (although now only in the "remnants") in Offences Act.

Offences defined in this Act, can be divided according to the level of complexity of legislation in relation to protection into:

a) specific offences, which can be further subdivided into general $₫ 45$ and segmental $₫ 35$

b) generally designed, for example $₫ 46$.

In the field of biodiversity protection, it is possible to consider, under the special part of Offences Act, the so-called offences, namely offences in the field of agriculture, hunting and fishing. This is the category of offences against individual environmental components, which can, however, have a significant impact on the protection of biodiversity, especially on the ecosystem and species protection. Finally, residual offences can be applied in order to achieve the protection of biodiversity, namely the offences in the field of environmental protection, and the so-called other offences against order in administration. 
The mutual proportion of offences in the field of environmental protection and its individual components regulated by special laws and offences in Offences Act is expressed by the speciality principle.

From the viewpoint of enforcing the principle of liability of a tortfeasor within liability in tort in the area of administrative and legal liability related to the protection of biodiversity, it is necessary to tackle both, individual issues of fact of administrative torts and their definition, sanctions and protective measures and conditions of cessation of liability.

Only a natural person can commit an offence. Article 6 of the Offences Act stipulates that a person who has acted or should have acted on behalf of a legal person is liable for the breach of obligation imposed on that legal person, and in case of an injunction, it is a person who awarded an order for such proceedings.

When we take a closer look at the individual provisions of laws in the area of biodiversity, then we find out that there are no problems with identifying a person who committed an offence.

Liability in tort of natural persons in the conduct of running their business and legal persons is based on the principle of strict liability. The absence of the element of fault differs by liability in tort of natural persons in the conduct of running their business from another liability in tort of natural persons.

In case of legal entities, environmental laws, unlike natural persons, do not distinguish whether they are commercial or non-commercial entities. Consequently, even associations can also, theoretically, commit an administrative offence, in whose articles of associations the protection of natural environment is the main scope of their business activity. ${ }^{3}$

The subjective side of the offence is mandatorily investigated only when it comes to offences, and in case of other administrative offences committed by legal and natural persons who run a business, the element of fault is not investigated. Liability is therefore strict, and the entity cannot be relieved from liability by their reference to contractual agreements or by breach that was caused from the side of their contractual partner.

In terms of environmental protection and in terms of the preventive function of liability modes, it is important to classify administrative offences according to the consequence of unlawful conduct. If the consequence lies in endangerment of protected values and interest, then we speak about the offences of criminal threat, in case the consequence lies directly in the breach of these values, then we speak about breach offences.

In practice, however, we can determine another group of administrative offences of a minor importance. It is unlawful conduct, but it does not reach the level of seriousness of the offence of criminal threat. Although this type of conduct does cause the breach of legal regulations, it is not a type of breach that will pose threats to the environment, but rather it is a breach of obligations related to the organisation of protection of a certain interest, therefore we speak about offences of administrative nature.

For such offences, we could indicate a breach of duty to notice or the duty to report (unless, of course, it is not the duty to report some serious accident or emergency incident), further, a breach of duty to register, a breach of duty to pay fees or other financial deductions or payments, a breach of duty to monitor, and a breach of duty in relation to control authorities. However, the failure to comply with the said duties has no direct impact on threats to the environment. 
Issues of the fact of administrative offences appear to a greater or lesser extent in the wording of many legal regulations in the area of biodiversity protection. Their number consequently also depends on the area which is regulated by the relevant legislation. Clearly, the largest number of them is in sections where a great emphasis is placed on monitoring activities, and therefore on keeping a variety of records and fulfilment of the duty of monitoring. A significant number of administrative offences can be also found in the legislation whose legal adjustments stem from the contents of international treaties.

In case of breach offences within the category of administrative offences, the consequence in the form of death of the object of an attack is directly implied. A typical example is killing of birds. Another consequence relates to damage, destruction, deterioration of state and so on. ${ }^{4}$

Some types of conduct are not considered to be unlawful, unless they cause a prohibited consequence defined by law. Interventions against pests, plant diseases and while taking hygiene measures are permitted by separate laws, but this conduct cannot endanger, over an acceptable limit, particularly protected components of nature.

Based on the inspiring ruling of the Czech Supreme Administrative Court, it is possible to document both, the issues of objective liability and the issues of proving the conduct and consequences of an administrative offence in the field of biodiversity protection. The said Court, in its ruling No. A 3 /2003-47, dated on the $24^{\text {th }}$ of February 2005 , held that the inadmissible use of organic or industrial fertilisers or any other chemical substantives is sufficient to fulfil the merits of the case of unauthorised interference with natural development of specially protected plant species, under the Nature and Landscape Protection Act; without, at the same time, the necessity of requiring the effect of destroying an individual, and a specially protected plant species. Even in case of another administrative offence, this is liability for unlawful conduct irrespective of fault.

Scientific literature dealing with the categorisation of the issues in the fact of administrative offences recognises, in practice, four types of categories. The most common type is defining the issues of fact by verbal description. The second unlawful act by unlawful interference with the natural development of specially protected case is a partial wording in combination with a reference to the provisions governing the duty which a liable person violated. For example, "a nature conservation authority will impose a fine of up to the amount of $€ 7,000$ on a natural person who commits an offence by damaging or destroying a cave and its part, or who violates other duties".

The third case occurs when the issues of fact only refer to the relevant provision of the law which is sanctioned. For example, "a natural person commits an offence if they sell or offer specimens in violation of the relevant provisions of Act No. 543/2002 Coll. on Nature and Landscape Protection".

The fourth option concerns other (residual) facts. For example, "a nature conservation authority will impose a fine of up to the amount of $€ 16,000$ on a legal or natural person, if in the conduct of their business they commit an offence by [...] killing birds or keeping birds, except those that may be hunted, or keeping specially protected animals without permission, or if they otherwise unlawfully interfere with their natural development".

Furthermore, in my view, it is also possible to distinguish cases where an act infringes directly some statutory provision, or it refers to the infringement of a specific 
administrative act issued under the law or some directly effective EU regulation. For example, an "administrative offence is committed by a natural or legal person - an entrepreneur who disposes of an exemplary species directly threatened by extinction in violation of an import license or another valid permit under this Act (Act No. 543/2002 Coll.) or under the regulation concerning trade in endangered species".

From the principle of nulla poena sine lege results the requirement for some legal form of expression of the type and amount of sanction, the conditions and manner of their imposition, as well as considerations for the assessment of the sanction in a particular case. For sanctions to serve their purpose, they must be designed, in terms of their kind and amount, in a way to match the nature and gravity of unlawful conduct, considering the property and other benefits obtained by that unlawful conduct, and so on. Even in the case of sanctions, it is necessary to distinguish sanctions imposed for offences and sanctions imposed for other administrative offences, whereby the type and amount of sanctions is, in particular, in case of administrative offences different than in offences laid down by individual laws. In this respect, it is not possible to omit the general provision of Article 29 of the Act on Environment, under which fines or other measures are imposed for a breach of duties stipulated by these special regulations. ${ }^{5}$

In case of offences, the law in the area of biodiversity protection mostly imposes a fine as a form of sanction. However, under the Offences Act, other forms of sanctions may also be applied in a subsidiary way, which means, for example, giving a caution, or imposing prohibition of an activity and a thing forfeit. In particular, the latter two may be relevant in the field, for example, while regulating the trade in threatened animal and plant species. Exceptionally, in case of offences, in special laws, it is possible to come across another sanction form, different from fines. For example, under the Hunting Act, "a government authority will impose a fine of up to the amount of $€ 1,200$ on a bunting license holder who commits an offence by violating some hunting rule; it may impose a ban on activity for the period of up to two years; alongside the ban, the hunting license is withdrawn; at the same time it is possible to pronounce a thing forfeit".

In case of other administrative offences committed by legal persons and natural persons who act as entrepreneurs, these groups of individuals are most likely to be fined, although there are other types of sanctions that can come into consideration, such as a ban on activity or a ban on farming.

Exceptionally, in case of offences, as well as in case of other administrative offences, it is possible to come across a recurrence in the area of biodiversity, which is a repeated breach of the same obligations. Usually, the relevant law combines repetition with a certain time limit. For example, under the Act on Zoological Gardens, "for an offence or other administrative offence stated in the Section [...] a fine of up to the amount of $€ 200,000$ may be imposed, if that offence has been committed repeatedly within the period of one year after the imposition of the fine on it".

In the environmental protection legislation, other institutes of sanctioning nature than fines are also entrenched. Although they are often not labelled as sanctions, they undoubtedly are some form of punishment for a recipient, by virtue of their nature. An important thing is that these are the institutes that may also be involved as a result of a breach of an obligation imposed by law, and in this sense, they may be included in 
the accountability scheme. An important element is, in most cases, also the public interest, which is also confirmed by the fact that the application of the instrument in question is not only permissible in connection with unlawful conduct, but often also in the absence of substantive conditions for the performance of certain activities or in the actual occurrence of the unlawful state. The confiscation or seizure of a thing does not preclude the simultaneous imposition of a fine.

In the area of biodiversity protection, we can come across the following types/tips:

1. instruments relating to entities - for example, in the form of authorisation or license withdrawal in the event of a serious breach of duties while performing special activities

2. instruments relating to activities of some place of business - usually in the form of bans, revocation, suspension or limitation of operation or refusal of an application

3. instruments relating to a thing - removal or seizure of a thing or a living animal that cannot be disposed of or kept. Typically, in the area of biodiversity protection, it involves a plant or an animal species, living or dead, or a product made from them, in case of unlawfully kept individuals within the category of particularly protected species, and these protective measures are implemented quite often ${ }^{6}$

The majority of the environmental protection laws, including the laws in the area of biodiversity, set deadlines in relation to the application of sanction liability. These are both of the subjective and objective nature. The Nature and Landscape Protection Act provides an exception to this, it regulates only the objective periods of time.

For example, "a fine, under sections 1 and 2, may be imposed not later than three years from the date on which the unlawful conduct was committed". It can come across as a failure of a lawmaker, but by looking back at the historical development of the legal adjustment of the Nature and Landscape Protection Act, we can come to a clear conclusion that this is an obvious intention in the stated examples.

The said Act, even before the Act on Regulation of Trade in Endangered Species came into force, contained the subjective period of time. However, after the Act on Regulation of Trade in Endangered Species had been amended, the said period was left out. This was probably due to the effort to facilitate a proceeding and to increase the possibility of imposing a timely fine.

The time limits for the imposition of a fine for committing an administrative offence are subject to preclusion, the passing of which is neither interrupted nor stopped as a matter of principle. The objective time limit is set only in case of offences. Provision 20 of Act No. 372/1990 Coll. on Offences, makes it impossible to deal with an offence if two years have passed since it was committed.

Some offences in the field of nature and landscape protection can also be qualified as criminal offences under the Criminal Code No. 300/2005 Coll., as altered and amended. To be precise, it concerns, in particular Article 300 on "threats and damage to environment", and Article 305 on "violation of plant and animal species protection", which are aimed at protecting the species of wild fauna and wild plants.

The conditions contained in these issues of fact are designed in a way to be consistent with the meaning of this general provision, and applicable to all objects of this crime (in 
other words, to the environment as a whole and to all its components), not only to plant and animal life. Articles 300 to 305 have been amended and their purpose is to clarify the provisions of the Criminal Code in question in order to cover all the proceedings required by the Directive, and follow the established system of listed national, European and international sources of environmental law.

The typical feature of crimes against environment is that, apart from some exceptions, all provisions refer to other generally binding legal regulations.

Crimes of threats and environmental damage (Articles 300 and 301) have a "general character" compared to other provisions, which means that in this paper, other offences are in the subsidiarity or specialty relation to them, and a single-action concurrence between the crimes of threat and harm to the environment with these crimes is therefore excluded.

In case of a deliberate form of criminal offences of threat and damage to the environment (Article 300 Section 2), the offender is punishable, if he unlawfully builds a building in a protected area. The offender can be any natural person (general entity) as well as a legal person who is subject to criminal liability. From the point of view of the subjective element of crime, a criminal offence under Article 300 requires deliberate culpability; in other words, specific intent, in case of a criminal offence under Article 301, negligence is required.

Punishability of a crime of threat and a crime of causing harm to the environment under Article 300 may, upon fulfilment of relevant conditions, lapse by applying effective regret (Article 85).

Less serious interventions in the environment may be sanctioned pursuant to Article 45 of Act No. 372/1990 Coll. on Offences as offences, and pursuant to Article 28 of Act No. 17/1992 Coll. on the Environment as administrative offences.

In the year of 2014, in the field of biodiversity protection, Regulation (EC) of the European Parliament and of the Council of the EU No. 1143/2014 of 22 October 2014 on the prevention and regulation of the introduction or planting and the spread of invasive non-native species was adopted. The impacts of the spread and the effect of invasive nonnative species on the biodiversity of geographically indigenous species and on natural ecosystems have been evident for a long time from the side of natural sciences - they pose one of the most serious sources of threats to biodiversity.

Article 30 Section 2 of the above-mentioned Regulation imposes an obligation on the Member States to lay down penalties for infringements of the provisions of this Regulation, provided that the Member States shall take all necessary measures to enforce these sanctions. The term "all necessary measures to enforce these sanctions" means, within the framework of the Slovak national law, the adoption of substantive and procedural standards in the field of liability in tort, including the determination of the powers of administrative or judicial authorities.

However, Article 30 Section 2 of the above-mentioned Regulation does not explicitly determine whether administrative liability or even criminal liability arises. It only indicates that sanctions are to be imposed, it provides their demonstrative calculation in paragraph 3, and it only sets out what their functions should be like; which means that these sanctions should be effective, proportionate and have a deterrent effect. Sanctions under Article 30 should be mainly introduced in cases of a breach of obligations under Articles 7, 8, 9, 10, 16, 17, paragraph 20, 31 and Article 32. 
From the point of view of the subjective aspect of the relevant type of unlawful act, it is possible to formulate both a deliberate and negligent act, and an omission to act, except for Article 7 where gross negligence is required. After the adaptation of Article 30 of the Regulation on the prevention and regulation of the introduction or planting and the spread of invasive non-native species within the Slovak national law, in my opinion, in the context of de lege ferenda considerations, there are two ways - legal liability will be regulated not only in the area of administrative law, but also in criminal law.

When it comes to the imposition of proper punishment, of course, offences committed by natural persons and other administrative offences committed by legal and natural persons, entrepreneurs who are subject to strict liability - come into consideration. In terms of sanctions, the types of sanctions calculated demonstratively correspond to Article 30 Section 3, in other words fines, further we speak about the seizure of invasive non-native species as well as the immediate suspension or withdrawal of a permit in accordance with Article 8.

When it comes to entrenching administrative punishment in case of offences, two options are in place - it is of course, the legal adjustment of the Offences Act (where the common arrangement for different cases would be an advantage); the second option would be the amendment process of sanctioning provisions in each individual segmental law which regulates this subject matter, for example in the Forest Act, Nature and Landscape Protection Act, Water Act, Hunting Act, etc.). ${ }^{8}$

From the perspective of other administrative offences of legal entities and natural persons who are entrepreneurs, only one option is possible, providing that there is the absence of a code listing other administrative offences, the option is to amend the sanctioning provisions in each individual segmental law that regulates this subject matter.

It is clear from the point of view of determining the relevant state administration authorities that in case of offences either general regulation of the authorities under the Offences Act will come into question, or the relevant control and sanctioning authorities will have to be determined in individual segmental laws. The already existing authorities, particularly the Slovak Inspectorate of the Environment and the state veterinary authorities, are in consideration. In the territory of national parks and protected landscape areas, the respective national park administration authorities could exercise these competences. Local authorities could be omitted because of the high level of expertise in the issue of control and imposition of sanctions and corrective remedies.

The area of criminal law is also considered, without doubts, but there is a question whether the requirement of the above-mentioned EU regulation is criminal liability, or whether it can be deduced. Such a requirement is absent. On the other hand, pursuant to Article 30 Section 2, sanctions that are determined must be effective, proportionate and deterrent. The expression "deterrent" could also mean the introduction of criminal liability.

Similar wordings are commonly found in the case law of the Court of Justice of the European Union, and in other sections of environmental law (CITAS, nature and landscape protection within the NATURA 2000 scheme, protection of the Earth's ozone layer, etc.), where, in the past, the European Union law enabled the introduction of criminal liability concept into the Slovak domestic law. ${ }^{9}$ 
As long as the Slovak Republic makes a decision to do so, it will be necessary to amend the Criminal Code, in order to complete the actus reus of a crime that deals with the most serious violation of the regulation, but only such proceedings that will not be determined as offences or other administrative offences at the same time - because such a duplication would be inadmissible. Sanctions could be then imposed, in particular, for the violation of the following obligations:

- failure to take preventive and regulatory measures

- failure to take measures to restore damaged ecosystems

- failure to make a notification

- breach of a relevant decision

- unlawful possession, or possession of an individual

This occurs, of course, on the condition that there is no duplication with offences or other administrative offences. Criminal offences must be defined in accordance with the ultra ratio principle.

The offender would be a natural person. It should be also considered whether it is necessary to establish such a crime also for legal persons. Again, duplication will not be possible, if there is a correctly defined administrative offence of legal entities in the relevant segmental laws.

From the point of view of giving the precise wording to the actus reus of crimes set out in the Slovak Criminal Code, it is possible to refer to the violation of a directly effective EU Regulation on the prevention and regulation of the introduction or planting and the spread of invasive non-native species, which is acceptable from the viewpoint of criminal law, for example this is the way how CITAS offences in the Czech Penal Code are dealt with.

In terms of specific sanctions in the area of criminal liability, it can be stated that the sanctions set out in the demonstrative calculation in Article 30 Section 3 on IND, can be also employed in the Criminal Code, and possibly, in the Act on Criminal Liability of Legal Entities. Since it is not an exhaustive calculation, it is possible to consider also introducing other sanctions, for example in the form of a custodial sentence or a ban in the area of environment protection.

In case of determining competent authorities, this subject matter, when it comes to adaptation, is no longer valid, since we speak about the already established criminal justice system.

\section{Conclusion}

I hold the view that de lege ferenda should be more focused on unification of the conditions of administrative punishment in the area of administrative liability for other administrative offences of legal persons and natural persons, who are entrepreneurs in the field of species biodiversity protection. Furthermore, the precise wording of the actus reus of 
offences and other administrative offences in the area of administrative punishment in case of persecution of threatened species of wild animals (especially when placing poisonous baits), and stating the conditions of liability in tort for the import and transport of invasive non-native species, including their regulation.

Definitions should concern not only amendments made to laws in the area of administrative liability and liability for environmental protection, but also the level of criminal law (Criminal Code and criminal liability of legal entities). The amendment process should be based on both the normative requirements of European legislation in the area of biodiversity protection, and at the same time, it should take into account the needs of the domestic practice. 


\section{References}

1 Richard B. Primack, Pavel Kindlmann, Jana Jersáková, Úvod do biologie ochrany př́rody [Introduction to the biology of nature protection] (Praha, Nakladatelství Portál, s.r. o., 2011).

2 Soňa Košičiarová, Ekologická ujma a škoda v práve životného prostredia [Ecological Damage and Damages in Environmental Law], 120 (Bratislava, Vydavatelské oddelenie Právnickej fakulty UK, 1997).

3 Milan Damohorský et al., Právo životního prostředí, 3. vydáni [Environmental Law, $3^{\text {rd }}$ edition] (Prague, C. H. Beck, 2010).

4 Branislav Cepek et al., Environmentálne právo. V'seobecná a osobitná čast' [Environmental Law - General and Special Part, $1^{\text {st }}$ edition] (Pilsen, Aleš Čeněk, s.r. o., 2015).

5 Helena Prášková, Východiska budouci právni úpravy správního trestáni [Background of the Future Legal Regulation of Administrative Punishment] (Prague, Právní praxe, 1999).

6 Lilla Garayová, Bioethics and Law in the Postmodern Society, 37-45, in Wissenschaftszeitschrift des Studienzentrums Hohe Warte conference proceedings (Sonderausgabe 2014 December).

7 Milan Damohorský, Legal Responsibility in Environmental Protection, 34, in Acta Universitatis Carolinae - Iuridica, no. 2 (2015).

8 Peter Potasch et al., Zákon o priestupkoch - Velký komentár [Law on Offences - Big Commentary] (Bratislava, Eurokodex, 2016).

9 Lilla Garayová, Sources of EU Law, 59-62, in Selected Sources of Law - Past and Current Perspectives (Bratislava, Paneurópska vysoká škola, 2019). 